\title{
RECENT DEVELOPMENTS IN FEDERAL TAXATION OF INTEREST TO THE RESOURCE INDUSTRIES \\ ROBIN J. MacKNIGHT
}

\begin{abstract}
This paper considers certain aspects of the proposed legislative changes to the Income Tax Act (Canada) and the Petroleum and Gas Revenue Tax Cut set out in the January 30, 1985 and May 9, 1985 Notices of Ways and Means Motions, the Western Accord and the federal budget of May 23, 1985 which may be of interest to advisers to the oil and gas industry. Certain of these changes have been incorporated in Bill C-72, which was passed October 29, 1985, and draft amendments to the Petroleum and Gas Revenue Tax Act released September 16, 1985.
\end{abstract}

\section{INTRODUCTION}

In a Notice of Ways and Means Motion tabled in the House of Commons on January $30,1985,{ }^{1}$ the federal government introduced amendments designed to reduce the powers of the Department of National Revenue $^{2}$ and to improve the administration of the tax collection function. On May 9, 1985, the government tabled a Notice of Ways and Means Motion ${ }^{3}$ proposing technical amendments designed to simplify and clarify the Income Tax Act ${ }^{4}$ to correct various technical deficiencies and to respond to submissions for improvements to the Act. In Mr. Wilson's budget of May 23, $1985^{5}$ proposals were introduced to implement the Western Accord reached on March 28, 1985, to encourage investment in the private sector, to restore federal fiscal responsibility and to further improve the fairness of the Canadian tax system.

The Minister of Finance introduced several discussion papers with the Budget which may have substantial impact on the way in which the oil and gas business is conducted. This paper will review the January Amendments, the May Amendments, the Budget proposals and the proposals set out in the Budget discussion documents ${ }^{6}$ as they may affect business planning and business structure. These issues have been broadly grouped under three headings:

- matters affecting corporate operations and structure;

- matters affecting employee compensation; and

- matters affecting tax compliance and collection.

- Associate, Bell Felesky Flynn, Calgary, Alberta.

1. Notice of Ways and Means Motion to Amend the Income Tax Act and Technical Notes, tabled in the House of Commons on January 30, 1985 (the "January Amendments"). This Motion proposes legislation designed to ensure that taxpayers will not be required to pay disputed income taxes until the conclusion of a court hearing and follows measures originally announced on November S, 1984 in the Government Speech from the Throne and referred to in Finance Minister Michael Wilson's Economic Statement of November 8, 1984.

2. Referred to herein as the "Department".

3. Notice of Ways and Means Motion to Amend the Statute Law Relating to Income Tax and to Make a Related Amendment to the Tax Court of Canada Act introduced in the House of Commons on May 9, 1985 (the "May Amendments").

4. S.C. 1970-71-72, c. 63, as amended (the "Act"). Unless otherwise identified all statutory references are to the Act.

5. Notice of Ways and Means Motion to amend the Income Tax Act, tabled in the House of Commons on May 23, 1985 (the "Budget").

6. The Budget Papers include the following: "A Minimum Tax for Canada"; "The Corporate Income Tax System; A Direction for Change": "A Corporate Loss Transfer System for Canada"; and "The Canadian Budgetary Process; Proposals for Improvement". 


\section{MATTERS AFFECTING CORPORATE OPERATIONS AND STRUCTURE}

\section{A. CORPORATE OPERATIONS}

\section{Matters Arising Out of the Western Accord}

Probably the most significant impact of the Western Accord was the proposal to eliminate the Petroleum and Gas Revenue $\operatorname{Tax}^{7}$ on new production after March 31, 1985 and to phase out the PGRT on current production over the three years 1986 through 1988.

\section{(a) Exempt Production}

Resolution 9 to the Notice of Ways and Means Motion to Amend the Petroleum and Gas Revenue Tax Act $^{8}$ proposes that an exemption be provided for "prescribed petroleum and gas production revenue" attributable to production after March 31, 1985. At the moment, no production revenue has been prescribed, although Resolution 9 states that such revenue will include production royalties and resource royalties. The budget papers indicate that the following will be exempt from PGRT: 9

(i) production revenue and royalties related to oil, natural gas and gas liquids produced from wells on which drilling began on or after April 1, 1985; and

(ii) incremental revenue from a new waterflood or tertiary oil recovery project certified by the Minister of Energy, Mines and Resources which commences injection of fluid, steam or other substances on or after April $1,1985$.

The following production will not be exempt from PGRT:

(iii) production revenue and royalties related to oil, natural gas and gas liquids produced from wells existing prior to April 1, 1985;

(iv) production revenue and royalties related to oil, natural gas and gas liquids produced from wells on which drilling commenced prior to April 1,$1985 ;$ and

(v) incremental production from wells where a deduction is taken in computing PGRT liability for capital expenditures related to a new tertiary oil recovery project. ${ }^{10}$

7. Petroleum and Gas Revenue Tax Act ("PGRT Act"), S.C. 1980-81-82-83, c. 68, Part IV, as amended.

8. Notice of Ways and Means Motion to amend the Petroleum Gas and Revenue Tax Act (the "PGRT Amendments") introduced in the House of Commons on May 23, 1985.

9. Draft legislation and draft regulations were issued in a Department of Finance release dated Sept. 16, 1985 (Release 85-153) (the "PGRT Draft").

10. Tertiary oil recovery projects are entitled to a deduction in computing production revenue in respect of their enhanced recovery capital expenditures pursuant to subsection 82(8) and section 82.1(2) of the PGRT Act, supra n. 7. The PGRT Draft proposes to implement an election procedure to deal with this matter. See proposed subsections 82(9) - (11), Supra, n. 9. 
Officials of the Department of Finance, have clarified certain other aspects of the proposed exemption:

(i) incremental production from a new waterflood project or new tertiary oil recovery project where injection commences on or after April 1, 1985 will be determined on the basis of the allowable production ratios granted by the Energy Resources Conservation Board. It appears that incremental production from the time the allowable is assigned will be exempt from PGRT;

(ii) incremental production not from new wells (for instance, production from reworking of wells or the addition of new compressor facilities) will not qualify for the PGRT exemption;

(iii) production from a new formation in an existing well will generally not qualify for the PGRT exemption. However, officials of the Department of Finance have indicated that if the ERCB shows that such production is equivalent to production which would have resulted from the drilling of a new well after March 31,1985, then production from that zone will qualify for the PGRT exemption. The Department of Finance generally views production from a new formation in the same light as incremental production from reworking an existing well so that such production will not be exempt from PGRT. Production from deepened wells may, however, qualify for exemption."1

(iv) where a well is drilled in a unitized area after March 31,1985 , the production which will be exempt from PGRT will be that portion of the unit production which can be reasonably allocated to the new well; and

(v) production from a well drilled in a shut-in field will be exempt from PGRT if the spud date of the well is on or after April 1, 1985.

\section{(b) Rate Reduction}

Resolution 3 of the PGRT Amendments sets out the new rates of tax payable under Division 1 of the PGRT Act in respect of petroleum and natural gas production revenue. The new statutory rates will be:

(i) 13.33 per cent for revenue attributable to production in 1986 (10 per cent effective rate after resource allowance);

(ii) 10.67 per cent for revenue attributable to production in 1987 (8 per cent effective rate after resource allowance);

(iii) 8 per cent for revenue attributable to production in 1988 (6 per cent ef fective rate after resource allowance); and

(iv) nil for revenue attributable to production after 1988 .

One of the questions that arose out of the Western Accord was whether these reduced rates of PGRT would apply to royalty income. Resolutions 2, 5 and 6 to the PGRT Amendments do not entirely answer this question. Production royalties and resource royalties received after 1985 by a taxpayer other than a non-resident person not carrying on an oil and gas business in Canada are to be included in production revenue under Divi-

11. PGRT Draft, subsection (1) proposes to add a definition of "deepened oil or gas well" the production from which (defined as "new deep production") will be exempt. See subsection 3(1) of PGRT Draft adding paragraphs $83(1)(\mathrm{g})$ and $(\mathrm{k})$ to the PGRT Act. 
[VOL. XXIV, NO. 1

sion I of the PGRT Act. As a result of this change, production royalties will become eligible for the resource allowance to preserve the current favorable tax rate thereon; however, there is no intention that resource royalties will become entitled to the resource allowance. Amendments will be forthcoming to also provide that neither production royalties nor resource royalties will be eligible for the $\$ 500,000$ exemption currently set out in s. 84.1 of the PGRT Act.

Once royalties are removed from Division II and taxed under Division I; the withholding obligation on the payors of such royalties ceases. Canadian resident taxpayers receiving production royalties and resource royalties in respect of production after December 31, 1985 will be required to include these royalties in their production revenue and will be required to file a PGRT return and pay PGRT directly. Canadian resident individuals will only be required to file PGRT returns if their annual royalties and production income exceed $\$ 10,000$. This administrative arrangement anticipates that most individual royalty holders (the Annex to the Western Accord estimates two-thirds) will get the full benefit of the $\$ 10,000$ exemption from PGRT liability proposed in the Western Accord and will avoid the difficulties which the Department might otherwise encounter in refunding tax to such individuals.

Certain problems might be encountered by payors of royalties until January 1,1986 as a result of price decontrol on June 1, 1985. It is not clear how the operator is to determine the amount to withhold where royalty holders have the right to take production in kind, and in fact exercise that right, taking and selling production on their own account under the terms of sales agreements they have negotiated independently of the operator. Prior to June 1, 1985, there was a uniform price and the determination of the withholding amount was an easy matter. However, with price decontrol, it may not be inconceivable that the sale price which an operator may negotiate for its share of production may be different from the sale price which a royalty holder may negotiate for its share of production. The question then arises as to how the operator, who has the onus of withholding, is to calculate the withholding amount and not be subject to further liability.

Until clarification is forthcoming from the Department of Finance, operators would probably be well advised to calculate the withholding obligation on the basis of their sale price for production and leave it to the royalty holder to make the appropriate adjustments for this PGRT liability when he files his PGRT return.

(c) PGRT Offset

One of the fundamental principles set out in the Western Accord was that assistance would be provided to companies which are not currently paying corporate income tax to reduce their PGRT liability otherwise determined. The mechanism set out in the Western Accord is implemented through Resolution 48 to the Income Tax Amendments and Resolution 8 to the PGRT Amendments. The system proposed is to allow a corporate taxpayer to designate certain amounts in respect of exploration and development expenses incurred by it which may be applied to offset PGRT liability. 
A corporation, other than a corporation exempt from tax under Part I of the Act (for instance, a pension fund resource corporation), may in each taxation year ending after March 31, 1985 designate certain amounts incurred by it in respect of exploration and development expenses. These designated amounts will be added to a new account to be entitled the cumulative of fset account ("COA"). A corporation may designate an amount up to the aggregate of:

(i) the lesser of:

- its current year's "prescribed Canadian oil and gas exploration expense" incurred in the year and after March 31, 1985; and

- its cumulative Canadian exploration expense ("CCEE") at the end of the year computed after the deduction for the year in respect of such expenses; and

(ii) the lesser of:

- thirty per cent of its "prescribed Canadian oil and gas development expense" incurred in the year and after March 31, 1985; and

- the amount by which thirty per cent of the balance of its cumulative Canadian development expense ("CCDE") at the end of the year exceeds the current year's deduction in respect of CCDE.

The amounts of Canadian exploration expense ("CEE") or Canadian development expense ("CDE") so designated will reduce the taxpayer's respective CCEE or CCDE.

Certain aspects of the COA warrant special attention:

(i) It appears that not all expenses incurred after March 31, 1985 will constitute eligible expenses. The term "Canadian oil and gas exploration expense", which is used in Resolution 48 of the Income Tax Amendments, is defined for the purposes of calculating resource allowance in Regulation 1206(1) to be, basically, CEE determined without reference to reclassified expenses which were originally thought to be CDE (for instance, expenses of drilling a gas well which was subsequently shut-in for more than one year so that the original expenses which were thought to be CDE were reclassified as CEE). Officials of the Department of Finance have indicated that this definition will not apply for the purposes of the offset calculation. Rather, eligible expenses will be defined along the lines of the definition of exploration expenses eligible for the "mining exploration depletion base" in Regulation 1203(2)(a). Eligible oil and gas exploration expenses will be those directly related to exploration activities, net of government assistance, and will not include expenses defined to be "Canadian exploration and development overhead expense" in Regulation 1206(1), which include overhead, administrative and financing costs attributable to exploration activities, salaries and wages of persons not directly involved in exploration and maintenance of equipment (unless "substantially all" is used in exploration activities).

The term "Canadian oil and gas development expense" will be similarly defined in the Regulations to refer to CDE incurred in the year and after March 31, 1985, net of all government assistance and overhead and financing costs.

(ii) The COA can be applied to PGRT liability arising on both production revenue and royalty revenue. 
(iii) The COA is an annual calculation. The amount which can be applied in any given year to reduce PGRT liability is thirty per cent of the increase in the COA from one year to the next. Thus it appears there may be no carry forward of COA balances. In other words, expenses designated and added to the COA account can only be applied once to the extent of thirty per cent, and, unlike CCDE, cumulative Canadian oil and gas property expense ("CCOGPE") or capital cost allowance pools, cannot be applied over a number of years, on a declining balance basis, to the full extent of the amount designated.

\section{Corporate Surtax}

As part of the Budget policy of deficit reduction, a temporary surtax of five per cent will be imposed on the federal income tax payable by corporations, with the exception of tax on income qualifying for the low small business tax rate. The surtax will be in place for the 18 month period commencing July 1,1985 and ending December $31,1986 .{ }^{12}$

The surtax will apply to federal corporate taxes otherwise payable before the deduction of various tax credits, including the share purchase tax credit, scientific research tax credit, investment tax credit, employment tax credit and the tax credits for foreign taxes and political contributions. The surtax will not affect the instalment obligations of corporations, nor will it affect provincial revenues.

It is also proposed that commencing January 1,1986 a tax will be levied for 2 years on the capital of larger financial institutions regulated under the Bank Act, ${ }^{13}$ the Quebec Savings Bank Act, ${ }^{14}$ and under federal and provincial trusts and loan corporation legislation. The tax will be at an annual rate of one per cent of the capital employed in Canada in excess of a $\$ 200$ million threshold.

\section{Take or Pay Obligations}

Normally when a vendor of Canadian resource properties which are the subject of a take or pay contract wishes to dispose of an interest in such lands, the purchaser will require some adjustment or other consideration to ensure that due allowance is made for the existing take or pay obligations charged against the lands. In particular, a purchaser might be willing to assume the obligation to make future deliveries of prepaid gas or oil if the purchase price of the property is reduced to reflect the take or pay obligation assumed or if other arrangements can be made to ensure that he will be indemnified by the vendor against any loss occasioned by the requirements of the purchaser to make future deliveries in respect of prepaid gas or oil.

Under the Act, any amounts received by a Seller (as defined in a sales contract) as payments in lieu of deliveries of gas or oil (generally referred

12. Resolution 39 of the May Amendments, supra n. 3, originally proposed that this corporate surtax would end on June 30,1986 . However, following the reconsideration of the deindexing of the old age security payments, the corporate surtax was extended six months to make up the revenue which otherwise would have been saved by de-indexing.

13. S.C. $1980-81-82-83$, c. 40 .

14. S.C. 1970 c. B-4 as amended. 
to as "take or pay payments") must be included in the income of the Seller by virtue of paragraph $12(1)(a)$. The Seller is then entitled to claim a reserve under paragraph $20(1)(\mathrm{m})$ against this income inclusion in respect of gas or oil not delivered, so that effectively the Seller is not required to include in taxable income amounts received in a current year in respect of the obligation to deliver in the future.

In the following year, the amount previously claimed as a reserve under paragraph $20(1)(\mathrm{m})$ is included in the Seller's income by virtue of paragraph $12(1)(e)$, subject to the Seller's claiming an additional reserve for that taxation year under paragraph $20(1)(\mathrm{m})$ for gas or oil which has been prepaid but which has still not been delivered. In the event the Seller repays the Buyer (as defined in the sales contract) an amount in respect of take or pay payments previously made, a deduction is allowed to the Seller for such repayment under paragraph $20(1)(\mathrm{m} .2)$. Thus, the amount repaid by the Seller to the Buyer will not be included in the Seller's income because of the offsetting income inclusion and deduction.

Paragraph $20(1)(m .2)$ requires the Seller to make a "repayment" in respect of the take or pay payment originally included in income under paragraph $12(1)(a)$. Concern had been expressed that a "repayment" could only be made by the Seller to the Buyer. Any payment made by the Seller as an indemnity to a third party purchaser of the Seller's interest in lands encumbered by a take or pay obligation would not be deductible to the Seller, yet the take or pay payment would be included in the Seller's income. Thus the Seller's income was overstated due to the denial of this deduction. A proposed new subsection $20(24)^{15}$ is designed to address this problem. Under this proposed amendment, where the Seller pays a reasonable amount to the purchaser of its interest in land in consideration of that purchaser's undertaking to satisfy the take or pay obligation, the amount paid by the Seller to the purchaser will be deductible in computing its income for the year of payment. The purchaser will effectively assume the Seller's tax position. The recipient will be deemed to have received the payment in the course of a business on account of services not rendered or goods not delivered before the end of the taxation year in which it received the payment and will include the payment in its income under paragraph 12(1)(a). To the extent the payment by the original Seller was in respect of continuing obligations to make deliveries in the future, the recipient would then be entitled to claim a reserve under paragraph $20(1)(\mathrm{m})$ to offset the amount included under paragraph $12(1)(a)$.

In order to make the provisions of the new subsection 20(24) apply, the payor and the recipient must make a joint election. An election can be made by notifying the Minister in writing on or before the earlier of the days on or before which either the payor or the recipient is required to file a return of income pursuant to section 150 for the taxation year in which the payment to which the election relates was made.

15. Supra n. 3, ss. 10(2); incorporated in Bill C-72, An Act to amend the statute law relating to income tax and to make a related amendment to the Tax Court of Canada Act ("Bill C72''), ss. 10(3). 
The proposed section 20(24) will apply to the 1982 and subsequent taxation years. To the extent that an election is made in respect of a year prior to the current taxation year, the election must be made on or before the day that is 90 days after the day on which Royal Assent is given.

\section{Settlement of Debts on Winding-up}

Under current rules, where a subsidiary owes a debt to its parent company which is settled or extinguished on winding-up, either without any payment or by payment of an amount less than the principal amount of the debt, that debt will be deemed to have been settled or extinguished on the winding-up by a payment made by the subsidiary and received by the parent of an amount equal to the parent's "cost amount" of the debt, if the parent so elects. ${ }^{16}$ In such event, the parent company will not realize any gain or loss, and the subsidiary will not be deemed to realize any gain on the settlement of such debt.

These rules do not address the situation where the parent owes an amount to the subsidiary which is settled or extinguished on a windingup. Under the current rules, the parent could realize a gain on the settlement of such debts unless arrangements were made prior to the windingup to repay the indebtedness. Such arrangements could well be unnecessarily complex and time-consuming. Accordingly, subsection 80(3) of the Act is proposed to be amended ${ }^{17}$ to provide that no gain or loss will accrue to either the parent or the subsidiary on a settlement or extinguishment of debts owing by one to the other by virtue of the winding-up of the subsidiary corporation. The parent must still file an election to ensure the application of the proposed subsection $80(3)$. This new provision will apply to debts settled after 1983 . Where a winding-up has occurred prior to the current taxation year, the election must be filed prior to December $31,1986$.

\section{Canadian Exploration Expenses}

The Budget proposes ${ }^{18}$ to broaden the definition of Canadian exploration expenses to include any expense incurred after March 31, 1985 for the purpose of bringing a new accumulation of petroleum or natural gas into production in reasonable commercial quantities where that production is not derived from an oil or gas well (see below) or from a mineral resource (which is defined in section 248 to include bituminous sands deposits, oil sands deposits or oil shale deposits). Such expenses must be incurred prior to the commencement of production from the accumulation in reasonable commercial quantities.

\section{Oil or Gas Well}

The Budget proposes ${ }^{19}$ that a well drilled from below the surface of the earth after March 31, 1985 will be excluded from the definition of oil or

16. Supra n. 4, ss. 80(3).

17. Supra n. 3, ss. 36(3); Bill C-72, ss. 37(3).

18. Supra n. 5, resolution 50.

19. Id. at resolution 51 . 
gas well to ensure that all such expenses qualify for the expanded definition of Canadian exploration expenses discussed above and will thereby be fully deductible in the year incurred (subject to the general restrictions as to the deductibility of CCEE generally). Such wells would include wells drilled as part of a gravity assisted drainage or recovery system.

Both of the foregoing amendments are in response to submissions made by taxpayers in Ontario who proposed to produce oil and gas by first drilling a "shaft" (which was arguably not designed to produce oil and gas or to determine its location or existence, and thus did not constitute an "oil or gas well" within paragraph $66(15)(\mathrm{g} .1))$ and then drilling "spokes" off this central shaft, below ground, from which oil or gas would be produced. These "spokes" would otherwise constitute "oil or gas wells" within paragraph $66(15)(\mathrm{g} .1)$. However, unless each spoke was the first well capable of production from an accumulation of petroleum or natural gas not previously known to exist, or was shut in for twelve months after its completion (the tests for an exploratory well set out in subparagraph 66.1(5)(a)(ii)), the expenses of drilling such wells would constitute CDE under clause $66.2(5)(\mathrm{a})(\mathrm{i})(\mathrm{B})$ and would be eligible for only a thirty per cent deduction.

\section{Valuation Costs and Costs of Disposition}

Under the current rules, costs incurred by a taxpayer in connection with the sale of Canadian resource properties are not specifically dealt with in the Act. Amendments are proposed ${ }^{20}$ to various provisions in the Act to recognize a taxpayer's proceeds of disposition as being net of any outlays or expenses made or incurred by him for the purpose of making the disposition and that were not otherwise deductible for the purposes of Part I of the Act.

\section{Tar Sands Processing}

Section 65 of the Act will be amended ${ }^{21}$ to clarify that the processing of tar sands beyond the crude oil stage constitutes a processing activity rather than a resource activity which qualifies for earned depletion. As the technical notes accompanying the May Amendments state, this change "simply improves the terminology and does not represent a change of substance".

\section{Thin Capitalization Rules}

The Act currently restricts the deductibility of interest on debt to "specified non-resident shareholders"'.22 Simply stated, in the case of a Canadian subsidiary wholly owned by a foreign parent, where the debt to

20. Supra n. 3, ss. $21(3)$ proposing to add new para. $53(1)(n)$; ss. $29(8)$ proposing to amend clause $66.2(5)(\mathrm{b})(\mathrm{v})(\mathrm{A})$; ss. $30(7)$ proposing to amend clause $66.4(5)(\mathrm{b})(\mathrm{v})$; ss. $30(8)$ proposing to add new para. $66.4(5)(\mathrm{c})$; the corresponding provisions in Bill C-72 are ss. 22(4), $30(8), 31(7)$ and $31(8)$ respectively.

21. Supra n. 3, s. 41 proposing to amend ss. 87(1.2) and repealing ss. 87(1.3) and (1.4); ss. 42(9) proposing to add new ss. $88(1.5)$.

22. Supra n. 4 , ss. $18(4)$ through (8). 
the foreign parent exceeds three times the parent's equity in the Canadian subsidiary, interest on the excess amount will not be deductible.

Subsection $18(6)$ presently sets out rules to deem a loan to have been made by a "specified non-resident shareholder" (as defined in paragraph $18(5)(b))$ where the loan is originally made by that shareholder to an accommodation party on the condition that it be on-loaned to the Canadian subsidiary. However, the present rules do not contemplate the situation where a third party makes a loan to the Canadian subsidiary which is guaranteed by a specified non-resident shareholder, nor does it contemplate the situation where a series of loans are made which ultimately result in a loan being made to the Canadian subsidiary.

Subsection $18(6)$ is proposed to be amended ${ }^{23}$ to anticipate the situation where a loan is made to an accommodation party on the condition that a further loan be made to the Canadian subsidiary. Such a loan will be deemed to be a debt incurred by the Canadian subsidiary to the person who made the original loan. This is apparently designed to prevent a series of loans from avoiding the thin capitalization rules. The proposed amendment still does not address the situation where a loan is made by an accommodation party but is guaranteed by a specified non-resident shareholder.

\section{B. CORPORATE STRUCTURE}

\section{Paid-Up Capital}

Resolution 8 of the Budget proposes that the paid-up capital of the class of shares be reduced where such shares are issued under scientific research ${ }^{24}$ or share purchase credit ${ }^{25}$ arrangements or as resource flow through shares. ${ }^{26}$ The amount of the reduction will be the amount by which the increase in the corporation's paid-up capital as a result of the issuance of the share (generally the amount paid to acquire the share or the amount of the resource expenditures undertaken to acquire the shares) is greater than the amount by which the consideration received by the corporation on the issuance of the share (which would generally be the same amount) exceeds:

(a) in the case of resource flow through shares, fifty per cent of the related resource expenses; or

(b) in the case of scientific research and share purchase tax credit shares, the amount of the tax credit associated with the shares.

In other words, the reduction of the paid-up capital of the corporation will be an amount equal to the tax credit designated in respect of the share or fifty per cent of the resource expenditures incurred.

By making the reduction in paid-up capital applicable to the class of shares issued, the Department is effectively requiring the issuing companies to create separate classes of shares to ensure that the paid-up

23. Supran. 3, ss. 9(4); Bill C-72, ss. 9(4).

24. Supra n. 4, s. 127.3 and Part VIII (ss. 194 and 195).

25. Id. at s. 127.2 and Part VII (ss. 192 and 193).

26. Id. at s. 66.3. 
capital of shares issued for cash consideration is not eroded when comparable shares are issued under the incentive provisions described above.

Paid up capital is, by virtue of paragraph $89(1)$ (c), calculated in respect of a class of shares. The paid-up capital of any particular share is merely its pro rata share of the paid-up capital of the class. Thus, where a shareholder pays $\$ 100$ cash for shares, while another shareholder incurs $\$ 100$ of resource expenditures as consideration for the corporation's issuing the shares, the paid-up capital of that class would be $\$ 200$. Under the proposed rules, the paid-up capital would be reduced to $\$ 150$, or $\$ 75$ per shareholder.

The object of the amendment is to ensure that on redemption the holder of a share who previously received tax deductions in respect of that share receives dividend treatment on the excess of the redemption proceeds over this "net" investment in that share. However, since paidup capital cannot be "traced" to particular shares, inadvertent taxation could arise where other shareholders who have paid full value for their shares are receiving a return of their capital or are having their shares redeemed. To prevent such inadvertent taxation, corporations would be well advised to create separate classes or series of shares"7 for each "tax shelter" financing.

\section{Successor Rules}

Generally, corporate acquisitions and reorganizations have recognized the potential adverse impact of the "streaming" rules ${ }^{28}$ which restrict the deductibility of resource expenses to income generated from the property held by, or proceeds of disposition of the property held by, the acquired company. The streaming rules most notably came into play in three situations:

(a) the acquisition of all or substantially all of the assets of a principal business corporation. ${ }^{29}$ Whether "all or substantially all" the properties have been acquired will be determined by comparison with the properties retained. Such comparison will take account of the relative values of the properties and the extent of operations thereon; ${ }^{30}$

(b) an amalgamation of principal business corporations; and

(c) the winding-up of a principal business corporation into another corporation.

Prior to an amalgamation or winding-up, steps were generally taken to ensure that the predecessor corporation with the most significant resource related pools also owned sufficient property to ensure that such pools would be fully utilized. One of the more notable instances of this type of planning is a corporate reorganization to ensure that the company

27. Id. Ss. $248(6)$ provides that a series of one class of shares will be considered to constitute a separate class for, inter alia, the purposes of computing paid-up capital attributable to that series.

28. Id. at ss. 66:6), (7), (8), (9), (11), (11.1), (11.2), (11.3), ss. 66.1(4) and (5), ss. 66.2(3) and (4), ss. 66.4(3) and (4), ss. 87(1.2) and 88(1.1).

29. See para. $66(15)(\mathrm{h})$ and $1 \mathrm{~T}-400$.

30. Wardean Drilling Co. Ltd. v. M.N.R. [1974] C.T.C. 190; 74 D.T.C. 6164 (F.C.T.D.). 
with the most significant tax pools became the parent company into which the other principal business corporation with substantial income was wound-up.

The May Amendments propose two significant changes to these rules:

(a) such rules will no longer apply on reorganizations within a corporate family; ${ }^{31}$ and

(b) these rules will become operative upon one corporation's acquisition of all or substantially all of the Canadian resource properties of the predecessor, rather than all or substantially all the assets used by the predecessor in its principal business (which would have included such items as pipelines, gas plants and other tangible equipment and property). ${ }^{32}$

The proposed amendments exempt from the application of the successor rules the amalgamation of a parent and a wholly owned subsidiary, the amalgamation of two or more wholly owned subsidiaries and the winding-up of a subsidiary in which the parent owns not less than ninety per cent of the issued shares of each class. ${ }^{33}$

Under the new proposals, any amalgamation of a parent company and one or more wholly owned subsidiary corporations or an amalgamation of two or more wholly owned subsidiary corporations will result in the amalgamated entity being deemed to be the same corporation as, and a continuation of, each predecessor corporation. The resource expenditure pools of the predecessor corporation will thus not become "streamed" but will be consolidated in the amalgamated entity. Deductions may then be claimed in respect of such pools against the income of the amalgamated entity without regard to the prior ownership of the property generating such income.

On a winding-up of the ninety per cent owned subsidiary, the parent will be deemed to be the same corporation as and a continuation of the subsidiary. The subsidiary's resource expenditure pools will similarly not be "streamed" but will be available to of fset income from properties previously held by the parent.

Both of these amendments are applicable to transactions commencing after 1982.

The Budget proposes further amendments to these rules where control of a corportion is acquired. ${ }^{34}$ At present, where control of a corporation changes, special rules set out in subsection $66(11.1)$ provide that the corporation becomes a "successor" corporation so that its unused resource exploration and development expenses become "streamed" and become deductible only against income derived from resource properties that were owned by it prior to the change of control.

31. Supra n. 3, s. 41 proposing to amend ss. 87(1.2) and repealing ss. 87(1.3) and (1.4); ss. 42(9) proposing to add new ss. 88(1.5); Bill C-72, s. 42 and ss. 43(9) respectively.

32. Id. at ss. $27(3)$ and (5) proposing to amend ss. $66(6)$ and (7); ss. 28(2) and (4) proposing to amend ss. 66.1(4) and (5); ss. 29(1) and (3) proposing to amend ss. 66.2(3) and (4); ss. 30(1) and (3) proposing to amend ss. $66.4(3)$ and (4); Bill C-72 at s-ss. 28(3) and (5), s-ss. 29(2) and (4), s-ss. 30(1) and (3) and s-ss. $31(1)$ and (3) respectively.

33. Supran. 29.

34. Supran. 5, resolution 49. 
Where the corporation subject to the change of control is not a principal business corporation, but has incurred such resource expenditures through a flow-through share financing or a joint exploration corporation renunciation, that corporation will not have any sources of income against which the resource expenses may be deducted. Thus the impact of the successor rules is to prevent such a corporation from ever deducting such expenses following its change of control.

Under the Budget proposals, the parent corporation in these circumstances would be allowed to deduct its resource exploration and development expenses to the extent of the resource income of the subsidiary (i.e. the corporation issuing the flow-through shares or the joint exploration corporation) for its 1985 and subsequent taxation years from resource properties owned by it at the time of the acquisition of control of the parent provided the parent corporation owned not less than ninety per cent of the issued shares of each class of the capital stock of the subsidiary at the time of the acquisition of control. It appears that this provision will be effective for changes of control occurring after November 12, 1981.

In order to invoke this new provision, the parent company, at the time of the change of control, must own not less than ninety per cent of the issued and outstanding shares of each class of the subsidiary. Accordingly, care will have to be taken to ensure that this ninety per cent level is reached before control of the parent corporation changes. This may give impetus to planning resource activities as joint ventures or partnerships of subsidiary wholly owned corporations to ensure that parent companies not involved in the oil and gas business will be able to preserve the value of their resource expenditures.

\section{Proposed Loss Transfer Rules}

One of the discussion papers released with the Budget is entitled "A Corporate Loss Transfer System For Canada" which espouses a system which would allow the transfer of losses within a commonly owned group of corporations. This proposal responds to the initiatives raised in the November 8, 1984 Economic Statement ${ }^{35}$ which stated that "increasing the ability to transfer tax deductions and credits within corporate groups deserves serious consideration and could reduce the complexity of business operations". ${ }^{36}$

This proposal has been issued as a discussion draft and the earliest that it will be considered for implementation will be tax years commencing in 1986. Public discussion and submissions are being encouraged.

Under the current rules in the Act, it is possible to transfer losses between corporate entities. In the oil and gas business, common methods of transferring "losses" (or more correctly, tax deductions in respect of exploration and development expenses) within corporate groups include the use of flow-through shares, joint exploration corporations, limited partnerships, inter-company charges and amalgamations and windings-up.

35. Dept. of Finance (Ottawa), "A New Direction for Canada: An Agenda for Economic Renewal"' (1984).

36. Id. at 41 . 
Some of these techniques complicate business arrangements unduly; some may be prohibited by the terms of various commercial agreements (for instance, covenants contained in loan documents); almost all are expensive in terms of legal, accounting and management time and cost.

The Budget proposal is designed to meet three objectives:

(a) to improve the equity and neutrality of the income tax system as between economic entities;

(b) to enhance the response of business to tax incentives provided by the federal government; and

(c) to increase the freedom of managers of business organizations to structure business operations in the most desirable way from a business point of view with less concern about adverse or uncertain income tax consequences.

The proposal is designed to be administratively simple and to introduce an element of certainty in business planning.

Under the proposal, ${ }^{37}$ loss transfers will be allowed between a subsidiary corporation and its parent or between subsidiaries within a corporate group. This system will operate through annual joint elections by the parties to the loss transfer. Losses may be transferred to more than one recipient corporation, and no requirement for compensation for the loss transfer will be imposed.

The loss transfer rules will not be available to, or will have restricted availability for, certain specified corporations, such as investment companies, mortgage investment companies, insurance companies, companies principally involved in renting real estate or leasing property, farm corporations, mutual fund corporations, co-ops, credit unions, nonresident owned investment corporations and deposit insurance corporations.

The proposed system includes an anti-avoidance rule which is designed to prevent the "renting" of losses.

Use of the loss transfer system will not affect the instalment base of the transferee corporation which receives the benefit of the loss transfer.

\section{(a) Loss Eligible for Transfer}

In a conscious decision to keep the system administratively simple, only current year's losses from business or property (excluding farm losses) can be transferred between corporate entities. This amount is referred to as the "eligible loss amount". Losses carried forward from prior years cannot be transferred.

\section{(b) Subsidiary Corporation}

Losses may be transferred between a parent and a subsidiary or between subsidiary corporations. A subsidiary corporation must be a taxable Canadian corporation (i.e. a Canadian corporation which is not statutorily exempt from tax). This subsidiary corporation must in turn be controlled by a taxable Canadian parent corporation. Further, the

37. The discussion paper proposes to add a new s. 110.2 to the Act - see pages 19 to 26 . 
parent, alone or indirectly through other subsidiary companies, must own at least ninety-five per cent of the outstanding shares of each class of the subsidiary corporation's capital stock, excluding fixed value preference shares.

\section{(c) Fixed Value Preference Shares}

"Fixed value preference shares" are shares of the capital stock of a corporation which provide no right or entitlement to the holder of the share, either pursuant to the terms and conditions of the share or under any other agreement relating to the share:

(i) to vote at any meeting of shareholders of the corporation, other than a right to vote provided under the governing statute of the corporation;

(ii) to dividends other than dividends which are:

- of a fixed monetary amount; or

- of an amount calculated as a percentage of:

- the paid up capital attributable to the share;

- the amount for which the share may be redeemed, acquired or cancelled by the corporation; or

- the issue price of the share.

Further, such percentage must not be variable. However, a percentage determined as an invariable percentage of market interest rates or by reference to an invariable difference between a prescribed rate and generally quoted market interest rates will suffice:

(iii) to receive on redemption, acquisition or cancellation by the corporation an amount in excess of the aggregate of 110 per cent of the amount of consideration for which the share was issued plus the amount of any declared and unpaid dividends or undeclared cumulative dividends; or

(iv) to convert the share into, to exchange the share for or to acquire any other property, other than pursuant to an agreement with a person dealing at arm's length with the corporation.

It appears that the rationale behind allowing the existence of such "fixed value preference shares" is to not preclude the operation of the proposed loss transfer rules in circumstances where shares more akin to debt than to equity have been issued (for instance, where "term preferred shares" have been issued by a corporation in financial difficulty).

\section{(d) Timing}

In order for losses to be transferred between corporations the transferor corporation must, throughout the taxation year in which the loss is incurred (referred to as the "loss year") be the parent corporation of one or more subsidiary corporations or be a subsidiary corporation of the parent corporation. Further, the transferee corporation must throughout the taxation year in which the loss year ends (referred to as the "income year") be a subsidiary corporation, a sister corporation or the parent corporation of the transferor. If these conditions are met, there may be deducted in computing the taxable income of the transferee for the income year the amount designated by the transferor and transferee in their joint election, to the extent that such amount does not 
exceed the transferor's eligible loss amount for the year and the aggregate of all prior designations in respect of its eligible loss amount for the loss year.

A judicious choice of fiscal year end will be essential to ensure that the maximum benefit can be achieved from the corporate loss transfer system.

\section{(e) Anti-avoidance Rule}

An anti-avoidance rule has been proposed to ensure that a corporation does not become a "subsidiary corporation" for the sole purpose of transferring losses. If under all the surrounding circumstances it may reasonably be considered that one of the main purposes for a corporation being or becoming a subsidiary corporation at a particular time is to reduce the amount of tax payable by any corporation by virtue of a designation of an eligible loss amount, the corporation will be deemed not to be a subsidiary corporation, so that no loss can be transferred.

The words of the anti-avoidance rule are remarkably similar to the provisions of subsection 247(2) of the Act which becomes operative when "one of the main reasons for such separate existence [of two or more corporations] in the year is to reduce the amount of taxes that would otherwise be payable under the Act'. Canadian courts have established that tax considerations may be one of the reasons for the separate existence of corporations under subsection $247(2)$ so long as they are not one of the main reasons. Presumably this test would be imported into the proposed new subsection 110.2(7). In particular, the onus on the taxpayer set out in The Queen v. Covertite $L t d{ }^{38}$ may apply to the test set out in this subsection. If so: ${ }^{39}$

... the taxpayer must:

(a) disprove the facts assumed by the Minister in reaching his conclusion; or

(b) convince the court that the inferences drawn by the Minister from the facts assumed were unreasonable and unwarranted; or

(c) add further facts capable of changing the whole picture and leading to different inferences pointing to the conclusion that the other reasons alleged have actually been prevalent.

\section{(f) Disposition of Shares}

Another anti-avoidance provision has been included in section 110.2 which is similar to subsection 55(1). Where an eligible loss amount is designated and a person who is not at arm's length with the transferor corporation disposes of shares of the capital stock of the corporation, or of a debt or other obligation of the corporation to pay an amount, and having regard to the compensation (if any) paid or payable in respect of the designation, it may reasonably be considered that one of the results of the designation is or will be to:

(i) reduce the amount of the gain from the disposition;

(ii) create a loss from the disposition; or

(iii) increase the amount of the loss from the disposition;

38. [1981] C.T.C. 464; 81 D.T.C. 5353.

39. Id. at $467 ; 5355$. 
the gain or loss of the taxpayer from the disposition will be computed as if such reduction, creation or increase had not occurred.

(g) Application of the New Rules

(i) Regulated Businesses

Consider the situation where an integrated oil company ("Oilco") operates a regulated gas transmission system through a wholly owned subsidiary ("Subco"). Subco must periodically appear before a regulatory board to have its cost of service determined. In this determination, the regulatory board will generally include a provision for income taxes payable on the rate of return earned by Subco on its equity investment in the regulated business.

If Subco was allowed to collect a cost of service amount which included a calculation of income taxes attributable to its operations, but Subco through other means did not in fact pay such income tax, Subco's rate of return could increase significantly. In the past, Subco might have reduced its taxable income by incurring exploration and development expenses which would be deductible in computing its taxable income. As a result of incurring such expenses, Subco might hold as assets shares of a corporation or direct an interest in oil and gas properties.

From a business standpoint, it might be preferrable to have Subco hold only assets which are directly used in its regulated business activities rather than holding assets which have value only from a tax reduction standpoint, and which are unrelated to its regulated business.

Under the proposed loss transfer rules, Oilco could create losses (for instance, by incurring resource expenditures or by claiming capital cost allowance) which it could transfer down to Subco to shelter Subco's taxable income from its regulated business. Alternatively, another subsidiary of Oilco which realized losses from its operations could transfer a portion of its losses to Subco to reduce Subco's taxable income.

(ii) Operations on Canada Lands

Consider the situation where an oil company ("Oilco") has a substantial interest in an exploration agreement on Canada Lands. Under the terms of the Canada Oil and Gas $\mathrm{Act}^{40}$ and the relevant Exploration Agreement, Oilco, as a participant in drilling and exploration operations on Canada Lands, will have significant potential statutory liability arising from operations (including, in particular, oil spills). In addition, Oilco will have to incur substantial expenses, many of which can be recognized for tax purposes. In determining how to structure its offshore activities, Oilco will want to maximize the tax deductions and at the same time minimize its risk of loss. Specifically, one might anticipate that Oilco wants:

- to retain all CEE, CDE and COGPE write-offs for itself;

- to claim capital cost allowance on any depreciable assets used in offshore activities;

40. S.C. $1980-81-82-83$, c. 81 . 
- to retain the investment tax credit in respect of any depreciable assets acquired for use in its of fshore activities;

- to deduct the interest expense on any funds borrowed to build a drill ship or to acquire other depreciable assets;

- to protect the drill ship or other substantial assets from potential claims arising out of of fshore operations; and

- to protect its other assets from any such claimants.

Let us consider the types of structure which Oilco might consider in structuring its of fshore activities.

(h) Subsidiary Operations

Oilco may start by transferring its interest in the Exploration Agreement into a subsidiary company ("Subco") under section 85 of the Income Tax Act. Oilco could then provide funds to Subco to incur exploration and development expenses using the joint exploration corporation renunciation provisions of the Act. ${ }^{41}$ This would provide Oilco with a deduction in respect of exploration and development expenses and yet would protect it from liability from operations. This result could not be accomplished by using flow through shares under section 66.3 , since a requirement of that section is that the shareholder (i.e. Oilco) must incur the expense solely in consideration for receiving shares of the company. If Oilco were to incur the expense, it would also incur the potential liabilities associated with the operations giving rise to that expense.

To be entitled to the interest deduction and capital cost allowance, Oilco must retain ownership of the drill ship. However, if Oilco operates the drill ship, liability could arise and accrue to it which dictates that Subco must be the operator. An interesting question arises as to whether interest will be deductible if Subco does not pay rent to Oilco. If Subco is using the equipment in its business, but is not paying any amount to Oilco, can it be said that Oilco has incurred an interest expense in connection with borrowed funds used to earn income from a business or property or to acquire property which will be used to gain or produce income?42

Another problem arises if Subco does pay rent because the drill ship may then become a "leasing property" within the meaning of Regulation $1100(17)$, so that Oilco's access to capital cost allowance would be restricted by Regulation $1100(15)$ to the amount of rent actually received from Subco.

If the drill ship was transferred to Subco under subsection 85(1), Subco would be entitled to claim capital cost allowance in respect of it. However, such entitlement has no value unless Subco has income - and income producing properties would probably be isolated from Subco's potential operating liabilities.

(i) Limited Partnership Arrangement

To protect Oilco's liability and yet allow it a claim for capital cost allowance in respect of the drill ship, Oilco and Subco could set up a

41. Supra n. 4, ss. 66(10.1), (10.2) and (10.3).

42. These are the tests required by para. $20(1)(c)$ to ensure the deductibility of interest expense. 
limited partnership under which Subco would act as general partner and Oilco would be the limited partner. Under this arrangement, Oilco could contribute the drill ship as its limited partnership contribution. Since the drill ship would be used by the partnership, unrestricted (to the extent of the rules set out in the Act) capital cost allowance could be claimed by the partnership, which could be allocated to Oilco as a net operating loss. If the partnership also assumed the obligation to repay any loans associated with the drill ship, interest expense would be deductible by the partnership on the basis that it was using the drill ship to earn income from a business or property. Again, such interest expense could be effectively allocated to Oilco as a net operating loss of the property (subject to the administrative practices of the Department concerning "tax equity" in the partnerships). ${ }^{43}$

The major difficulty with this proposal is that there is no certainty that Oilco will have limited liability. Given that the limited liability of a limited partner is expressly governed by provincial statutes, there is considerable uncertainty as to whether limited liability remains where operations are carried on beyond the bounds of the province conferring limited partnership status. In most jurisdictions there is reciprocal legislation which confirms that a limited partnership established under the law of one jurisdiction will be recognized as a limited partnership under the law of another. ${ }^{44}$ However, operations on Canada lands are not subject to the laws of any province but are subject to federal jurisdiction. There being no federal reciprocating legislation which would affirm limited partnership status, there can be no assurance that Oilco's liability would be limited. ${ }^{45}$

\section{(j) Loss Transfer Structure}

Under the proposed loss transfer rules, Oilco could create a subsidiary ("Subco") which would incur all debt related to the drill ship and would operate it directly. Under such circumstances, Subco would be entitled to claim capital cost allowance, on an unrestricted basis, since the drill ship would constitute an asset used in carrying on its business and would not be a leasing property under Regulation 1100(17). Subco would be entitled to deduct interest expense on debt associated with the drill ship since it was being used to gain or produce income from the business or property carried on or owned by Subco.

Subco would realize net operating losses as a result of claiming such deductions which would qualify as "eligible loss amounts" and which could be transferred to Oilco under the proposed rules.

Oilco could continue to provide funds to Subco to incur exploration and drilling expenses under the joint exploration corporation rules. Sub-

43. See D.H. Watkins, "The Demise of the 'Equity Interest' Rule?", (1984) 1:10 Canadian Current Tax; Brian R. Carr and John A. Zinn, "Section 103 and the 'Equity Interest' Rule", (1985) 1:13 Canadian Current Tax.

44. See, e.g., Limited Partnership Act, R.S.O. 1980, c. 241, s. 24; Partnership Act, R.S.A. 1980 , c. P-2, as am. ss. $51(1.1)$.

45. Refer to Lyle R. Hepburn, Limited Partnerships, Richard DeBoo, Toronto, 1984, page 237 et seq. 
co, as operator, would be liable for any operating risk associated with the offshore activities and its liability would be limited to its assets. Thus the assets of Oilco which are not dedicated to activities on Canada lands would be isolated and protected from the risk of loss associated with such activities.

\section{MATTERS RELATING TO EMPLOYEE COMPENSATION}

Several changes were contained in the Budget and the May Amendments relating to taxation of individuals which may affect compensation packages provided to employees. In particular, corporate policies concerning stock options, housing loans and deferred compensation arrangements may have to be reviewed in light of the Budget proposals.

\section{A. EMPLOYEE STOCK OPTIONS}

As one of the corollary changes flowing from the proposal to create a lifetime exemption of up to $\$ 500,000$ of capital gains, amendments had to be made to the employee stock option rules. ${ }^{46}$ However, these changes only apply to stock options issued by Canadian controlled private corporations. For such corporations, stock options acquired after May 22, 1985 by an arm's length employee will give rise to a taxable employment benefit in the year the share is sold equal to fifty per cent of the difference between the fair market value of the share at the time the option was exercised and the exercise price, provided the share was owned by the employee for at least two years. Any gain accruing on the share after the employee acquires it will be eligible for the capital gains exemption.

\section{B. HOUSING LOANS}

Subsection $80.4(1)$ of the Act provides that where a person receives a loan by virtue of his of fice or appointment, he will be deemed to receive a taxable benefit equal to interest payable on the loan calculated at prescribed rates minus the interest actually paid. Prior to 1982 , no benefit was deemed to arise on the first $\$ 50,000$ of a housing loan. The 1981 amendments to the Act introduced transition rules to make section 80.4 applicable to the full amount of a housing loan as well as other employee loans. ${ }^{47}$ It is now proposed that a reduction in the taxable benefit resulting from a housing loan be reintroduced. The reduction will apply to a loan made to an employee who moves after May 23, 1985 to a residence at least 40 kilometres closer to his new work location than was his previous residence. The reduction in the benefit will apply for a period of five years from the date of the loan. During that period no benefit will be deemed to arise on the first $\$ 25,000$ of a housing loan.

\section{PRIZES AND AWARDS}

Paragraph 56(1)(n) of the Act currently provides that scholarships, fellowships, bursaries or a prize for achievement in a field of endeavor ordinarily carried on by the taxpayer will not be subject to tax unless and

46. Supran. 5, resolution 18.

47. Supra n. 4, ss. 80.4(5). 
to the extent such amount exceeds $\$ 500$. Resolution 37 of the May Amendments proposes to amend this paragraph to tax all prizes which have been received after May 23, 1985 if the prize is awarded in connection with employment or a business. This amendment appears to be a statutory reaction to the decision in The Queen v. Savage, ${ }^{48}$ in which the Supreme Court of Canada held that an employee who received $\$ 300$ from her insurance company employer for her success in insurance examinations was not taxable on that amount by virtue of paragraph 56(1)(n).

\section{NORTHERN BENEFITS}

The Budget does not contain any provisions to legislatively amend the current tax treatment of northern allowances. As part of the November 8, 1984 Economic Statement, the government announced that it was extending the remission orders in respect of certain allowances and benefits paid to persons residing in the north and other isolated communities. This extension applied until the end of 1985 . There are apparently continuing discussions with the appropriate government departments (including the Department of Indian Affairs and Northern Development) as to how this matter should be resolved.

The Budget papers indicate that the federal government will, on a case by case basis, extend this policy to exempt severance pay and termination payments from tax in the case of closure of the principal industry in remote communities where alternative employment opportunities are limited. It is understood that this policy has been implemented in at least one case.

\section{ADMINISTRATIVE AMENDMENTS}

\section{A. CLEARANCE CERTIFICATES}

Prior to distributing corporate assets on a winding up or liquidation, subsection 159(2) requires the "liquidator" to ensure that outstanding tax assessments have been satisfied. Further, subsection 150(3) requires the liquidator (referred to in the proposed amendments as the "responsible representative") to file a tax return on behalf of the corporation being wound up or liquidated.

The May Amendments propose to expand the application of subsection 159(2)..$^{49}$ The current section applies to "every assignee, liquidator, administrator, executor and other like person, other than a trustee in bankruptcy". As amended, the subsection will apply to "every person (other than the trustee in bankruptcy) who is an assignee, liquidator, receiver, receiver-manager, administrator, executor or any other like person ... administering, winding-up, controlling or otherwise dealing with the property, business or estate of another person"'.

In addition to clarifying the person who must obtain the certificate under subsection 159(2), the proposed amendment extends the matters which must be covered by the certificate. Previously, the certificate stated only that "taxes, interest or penalties that have been assessed under this

48. [1983] C.T.C. 393; 83 D.T.C. 5409.

49. Supra n. 3, s. 86; Bill C-72, s. 90. 
Act and are chargeable against or payable out of the property" have been paid or that security for their due payment has been accepted by the Minister. Under the new rules, the Minister shall certify that all amounts:

(a) for which any taxpayer is liable in respect of the taxation year in which the distribution is made or any preceding taxation year; and

(b) for the payment of which the responsible representative is or can reasonably be expected to become liable in this capacity as the responsible representative;

have been paid or that appropriate security for their due payment has been accepted by the Minister. The extension now applies to the tax liability of any taxpayer and covers all possible taxation years, not merely those in respect of which an assessment has been issued.

A further amendment to subsection 159(3) is proposed. Formerly, a person who made a distribution without obtaining the certificate was personally liable for the unpaid taxes, interest and penalties. The proposed amendment would clarify that the person who fails to obtain a clearance certificate is personally liable for the payment of taxes, interest and penalties only to the extent of the value of the property distributed.50

A recent decision of the Saskatchewan Court of Queen's Bench indicates that the Department will not rely only upon subsection 159(2) and (3) in ensuring that outstanding taxes are collected. In The Queen v. The Sands Motor Hotel Ltd. et al, ${ }^{51}$ the Crown applied for an order under the "complainant" provisions of the Saskatchewan Business Corporations $\mathrm{Act}^{52}$ to set aside dividends and redemption of certain preferred shares so that amounts paid out by the corporation would be repaid and would be available for the due payment of the corporation's income tax liability.

In this case, the taxpayer corporation sold its sole property and in anticipation of receiving income on the sale of the property declared substantial dividends. Subsequent to the sale of the property and the declaration of the dividends, but before their payment, the Department advised the taxpayer corporation that it proposed to tax the gain on the sale of the property as an adventure in the nature of trade (i.e. income rather than capital gain). Notwithstanding this advice from the Department, the taxpayer proceeded to pay the dividends which had previously been declared. When the Department subsequently issued its Notice of Reassessment (in respect of which Notices of Objection were duly filed) the taxpayer advised the Department that, having distributed the proceeds received from the sale of its assets, it had no other assets from which it could meet its income tax liability.

50. The Department's policy appears to already reflect this proposal. See IT-368, paragraph 3.

51. [1984] C.T.C. $612 ; 84$ D.T.C. 6464.

52. A complainant is defined in paragraph 231(b) of the Business Corporations Act as:

1. a registered holder or beneficial owner, and a former registered holder or beneficial owner, of a security of a corporation or any of its affiliates;

2. a director or an of ficer or a former director or of ficer of a corporation or of any of its affiliates;

3. the Director; or

4. any other person who, in the discretion of a court, is a proper person to make an application. 
The Crown subsequently brought an application under section 234 of the Business Corporations Act which allows a complainant to apply for a court order if the court is satisfied that any act or omission of the corporation, or the conduct of the business or affairs of the corporation, or the exercise of the powers of the directors of the corporation have been oppressive or unfairly prejudicial to a creditor or unfairly disregard the interests of that creditor. Under this section, the court may make such order as it thinks fit, including an order varying or setting aside transactions or contracts to which the corporation is a party.

The taxpayer asserted that the Crown was not a creditor of the corporation and accordingly had no standing as a complainant. However, relying on the decision in The Queen v. Simard-Beaudry Inc., ${ }^{53}$ the Saskatchewan Court of Queen's Bench concluded that there was a debt owing by the taxpayer to the Crown at the time that the letter was written to the taxpayer indicating that it would be assessed for tax on an income basis, although the exact amount of that debt had not been ascertained.

As to the standing of creditor to bring an application under section 234 as a complainant, the Court concluded that: ${ }^{54}$

The provisions of section 234 of the BCA expressly provide that it is to protect, among others, creditors, from acts or conduct that is oppressive or unfairly prejudicial to or that unfairly disregards the interests of any creditor.

If the applicant cannot be a complainant then I fail to see who is to complain on her behalf. If a creditor does not come within the definition of complainant one wonders how a creditor can obtain remedies for breaches of those provisions of the BCA which are obviously inserted for the protection of creditors such as the solvency test contained in sections 34 and 40.

It would seem to me that in the circumstances the applicant is a proper person to make an application. I therefore exercise the discretion granted to me by paragraph 231 (b) and hold that the applicant in this case is a complainant within the provisions of section 234.

The Court then went on to consider whether the corporation's payment of dividends violated section 40 of the B.C.A. which provided that the corporation shall not declare or pay dividends if there are reasonable grounds for believing that the corporation, after the payment, would be unable to pay its liabilities as they become due. The Court concluded that: 55

There were certainly reasonable grounds for believing that after those payments the taxpayer would be unable to pay its liabilities as they became due and in particular that it would be unable to pay the additional income taxes that it had been advised were in the process of being assessed.

In my opinion the payment by the taxpayer of the dividends when it could not meet the solvency test set forth in section 40 of the BCA was an act that effected a result that was unfairly prejudicial to and unfairly disregarded the interests of Her Majesty The Queen as a creditor of the taxpayer and the applicant is entitled to an order under section 234 .

The Court concluded that the payments by the corporation to its shareholders should be set aside and that the corporation should forthwith take steps to recover the payments made to the shareholders. The corporation was further prohibited from distributing or otherwise

53. 71 D.T.C. 5511 (F.C.T.D.).

54. Supra n. 48 at 615.

55. Id. 
disposing of the assets it was to recover from the shareholders until the payment in full of the monies owing to the Crown under the Income Tax Act and the assessments issued thereunder.

\section{B. SOURCE DEDUCTIONS}

Presently, subsections 227(4) and (5) provide that source deductions withheld by an employer are to be held in trust for the Crown and are to be kept separate from the employer's other monies. Subsection 227(5) also provides that in the event of liquidation, assignment or bankruptcy, the amounts deducted or withheld by a person do not form part of his estate.

At present, the general rule is that the Crown ranks in bankruptcy, for unpaid taxes, as a simple contract debtor with a priority over other contract debtors of equal degree, unless the Crown has, by legislation, either expressly or impliedly abrogated that right. ${ }^{56}$ However, a secured creditor (for instance a bank which appoints a receiver) will have priority over the Crown for its claims. ${ }^{57}$

Proposed changes ${ }^{58}$ will strengthen Revenue Canada's ability to recover amounts owed by employers who fail to remit source deductions on behalf of employees and other persons. The proposed amendment would create a priority in favour of the Crown over the claims of most other creditors. The priority would apply to unremitted source deductions for the 90 day period preceding the earlier of the date of liquidation, assignment, receivership or bankruptcy of the employer or the date of an assessment of the employer for such deductions. The amendment is proposed to be effective for amounts deducted or withheld after May 23, 1985. The property over which the Crown will have a priority will include all assets of the non-remitting person, without regard to whether they are subject to liens, charges or encumbrances or are held free and clear.

\section{INTEREST ON PAYMENTS AND REFUNDS}

A taxpayer presently must pay interest on late payments of tax owing and is correspondingly entitled to receive interest on amounts of tax refunded. Interest in both cases is calculated at prescribed rates. Current provisions in the Act are silent as to whether interest is computed on a simple basis or a compounded basis.

A proposed amendment ${ }^{59}$ to the Act would extend the payment of interest to late payments of penalties and to refunds of penalties. Further, the amendment will provide that all interest charged or paid with respect to tax, including instalments and penalties, will be compounded under the prescribed rules on a quarterly basis.

This measure will apply after Royal Assent on a date to be fixed by proclamation.

56. Miller v. Harron [1956] C.T.C. 102; 56 D.T.C. 1053 (Ont. S.C.); The King v. Lithwick (1921) 1 D.T.C. 6 (Ex.).

57. Bank of Nova Scotia v. Middleton Motors Ltd. 78 D.T.C. 6307 (N.S.S.C.T.D.).

58. Supran. 5 , resolution 59.

59. Id. at resolution 61 . 


\section{NON-RESIDENT WITHHOLDING TAX}

One of the frequent exemptions used in long term financing is subparagraph 212(1)(b)(vii) which provides that no withholding tax is exigible on interest payable by a corportion resident in Canada to an arm's length recipient where the indebtedness was issued after June 23, 1975 and before 1986 if, under the terms of the obligation or any agreement related thereto, the corporation may not be obliged to repay more than twenty-five per cent of the principal amount of the obligation within five years from the date of issue of that obligation, except in the event of a failure or default under the terms of the obligation. It is proposed to extend this exemption to any obligation issued before $1989 .{ }^{60}$

It is interesting to note that this subparagraph was originally introduced in 1975 applicable in respect of any obligation issued after June 23, 1975 and prior to 1979.61 The proposed extension of the sunset date for subparagraph $212(1)(b)$ (vii) to 1989 is the third such extension. ${ }^{62}$

\section{E. TAX COLLECTION PROCEDURES}

Under the January Amendments, it is proposed that a taxpayer will not be required to pay disputed taxes, interest or penalties until after the first judicial hearing of the objections to the amounts assessed. The proposed legislation also contemplates the repayment of such amounts previously paid to the extent that the amount is in controversy.

There are three components of the proposed amendments:

- restrictions on collection proceedings;

- repayment of taxes in dispute; and

- safeguards against taxpayer abuse.

\section{Restrictions on Collection Proceedings}

Subsection 158(1) requires a taxpayer to pay any part of the tax assessed within thirty days from the date of mailing of the Notice of Assessment. The Department may commence collection proceedings after this thirty day period, even if an objection to or an appeal from such assessment is outstanding.

The January Amendments propose to change this rule ${ }^{63}$ so that any tax assessed which is unpaid is payable forthwith by the taxpayer. However, the taxpayer does have a ninety day period immediately following the mailing of the assessment to file a Notice of Objection to the assessed amount. A proposed new section 225.1 would prevent the Minister from taking formal collection proceedings during this ninety day period.

Where the taxpayer does not file a Notice of Objection to an assessment and has not paid the assessed amount, formal collection proceedings may be commenced after the ninety day period has expired.

60. Id. at resolution 62 .

61. Supra n. 4, subpara. 212(1)(b)(vii) was added by S.C. 1974-75-76, c. 71, s-s. 11(1).

62. The first extension, to 1983, was introduced by S.C. 1977-78, c. 1, s-s. 92(3), applicable after March 31, 1977; the second extension was introduced by S.C. 1980-81-82-83, c. 140, ss. $118(3)$, extending the sunset date to 1986, applicable after June 28, 1982.

63. Supra n. 1, s. 11, proposing to add a new s-s. 225.1; Bill C-72, s. 115. 
Where a Notice of Objection is filed by the taxpayer, collection proceedings in respect of the amount in question will be delayed while the objection is under consideration by the Department and throughout the period during which the taxpayer may institute an appeal from the Department's decision on the objection. ${ }^{64}$ Thus in these circumstances any formal collection action by the Department will be delayed until ninety days after the notice is mailed to the taxpayer that the Department has either confirmed or varied the assessment.

Where the taxpayer further appeals the Department's confirmation or variation to the courts within the statutory ninety day appeal period, 65 the Department will not take collection proceedings until:

(a) where the appeal is to the Tax Court of Canada, before the day of mailing of a copy of the decision of the Court to the taxpayer; or

(b) where the appeal is to the Federal Court Trial Division, before the day on which the judgment of the court is pronounced or the day on which the taxpayer discontinues the appeal, whichever is earlier.$^{66}$

If the taxpayer loses his first appeal to the courts, he must pay the amount at issue or post security for such amount with the Department even if he intends to appeal the court decision. ${ }^{67}$

Notwithstanding that the taxpayer may not be required to pay the taxes in dispute until a determination as to his liability is made by a court of competent jurisdiction, there is significant potential cost to the taxpayer. If he ultimately loses his appeal, interest compounded at prescribed rates will be payable from the date on which the taxes in dispute should originally have been paid. ${ }^{68}$ In addition, the Tax Court of Canada or the Federal Court Trial Division may, on the application of the Minister, order the taxpayer to pay an additional amount not exceeding ten per cent of the amount in controversy if it determines that there were no reasonable grounds for the appeal and that one of the main purposes for instituting or maintaining the appeal was to defer the payment of tax. ${ }^{69}$

\section{Repayment of Tax}

A new subsection $164(1.1)$ is proposed to be added ${ }^{70}$ under which a taxpayer may apply in writing to the Minister for a repayment of taxes previously paid or a surrender of security to the extent that:

(a) the lesser of:

(i) the aggregate of the amount so paid and the value of the security; and

64. Id., proposing to add a new s-s. 225.2.

65. Supra n. 4 , s. 165.

66. Supra n. 60 , proposing to add a new s-s. $225.1(3)$.

67. Supra n. 1, s. 8 proposing to amend s-s. 220(4.1); Bill C-72, s. 113. The proposed amendment would require the Minister to accept adequate security furnished by or on behalf of the taxpayer for payment of the amount in controversy while the objection or appeal is outstanding.

68. Supran. 59.

69. Supra n. 1, s. 6 proposing a new s-s. 179.1; Bill C-72, s. 95.

70. Id. at s. 5; Bill C-72, ss. 93(1). 
(ii) the amount so assessed exceeds

(b) the amount, if any, so assessed that is not in dispute.

The taxpayer may only invoke this procedure if he has served a Notice of Objection to an assessment which the Minister has not confirmed or varied within 120 days of the date of service, or has appealed from an assessment to the Tax Court of Canada or the Federal Court Trial Division.

The Minister shall repay the taxes not at issue or surrender the security "with all due dispatch". The Minister may direct that no repayment of amounts be made or that security not be surrendered where "it may reasonably be considered that collection of all or any part of an amount assessed in respect of a taxpayer would be jeopardized by a repayment of an amount or surrender of security to the taxpayer". ${ }^{71}$ In such event, the Minister must give notice of that direction to the taxpayer by personal service or by registered letter addressed to the taxpayer at his last known address.

These new rules are intended to apply to:

(a) Notices of Assessment mailed after 1984;

(b) Notices of Objection served after 1984; and

(c) Appeals from assessments objected to after 1984.

3. Safeguards Against Taxpayer Abuse: The Taxpayer's Bill of Rights

On February 28, 1985, the Minister of National Revenue announced the Taxpayer's Bill of Rights. This "Bill of Rights" does not actually create new rights; rather, it sets out in writing what taxpayers have a right to expect in their dealings with the Department.

Four "rights" are conferred:

(a) the right to access to full, accurate and timely information about the Act and the taxpayer's rights under it;

(b) the right to an impartial determination of law and facts by the Department and to have only the correct amount of tax, no more and no less, collected;

(c) the right to courtesy and consideration in dealings with the Department; and

(d) the right to be presumed innocent unless there is evidence to the contrary. However, this presumption of innocence does not change the onus on the taxpayer to establish that the Minister's assessment is incorrect. ${ }^{72}$

In addition, the declaration of taxpayer rights makes reference to three statutory rights contained in the Act:

(a) the right to privacy and confidentiality concerning personal and financial information provided to the Department;

(b) the right to an independent review of objections by an appeals of ficer of the Department; and

71. Id., proposing to add a new s-s. 164(1.2).

72. M.N.R. v. Johnston [1947] C.T.C. 258; 3 D.T.C. 1065 (Ex.). 
(c) the right to withhold payment of disputed taxes in formal objections filed after January 1, 1985 (this presupposes that the January Amendments will be passed into law).

Further, the declaration of taxpayer rights states that:

You have a right to arrange your affairs in order to pay the minimum tax required by law. You can also expect your government to administer tax law consistently, and to apply it firmly to those who try to avoid paying their lawful share.

One can only hope that this statement reflects the Department's acceptance of the Supreme Court of Canada decision in Stubart Investments Ltd. v. The Queen. ${ }^{73}$ 